International Journal of Engineering \& Technology, $7(2.29)(2018) 899-904$
International Journal of Engineering \& Technology
SPC
Website: www.sciencepubco.com/index.php/IJET
Research paper

\title{
Differentiation Strategy of Soes Construction Service in Indonesia: A Point of View of Project Managers
}

\author{
Siddik Siregar ${ }^{1 *}$, Eddy Irsan Siregar ${ }^{2}$ \\ ${ }^{1}$ Doctor Of Research Management, Binus University \\ ${ }^{2}$ Lecture In Muhammadiyah Jakarta University \\ *Corresponding Author E-Mail: Siregarsiddik@Yahoo.Com
}

\begin{abstract}
This research is an empirical study on State-Owned Enterprises [SOEs] Construction Service in Indonesia. The main objective of this study is to analyze the variables concerning the performance of innovation management and information \& communication technology [ICT]. The study population is managers and decision makers on large-scale SOEs Construction Service in Indonesia. Respondents in this study are nine SOEs on Construction Service and the people involved in the construction service business with a total of 102 people. The respondents' answers are developed from theoretical framework and processed using confirmatory analysis of SEM [Structural Equation Modeling] that processed by SPSS AMOS 22 Program. The research results show that: [1] Innovation Management affects Differentiation Strategy significantly. [2] Innovation Management affects Company Performance. [3] Information and Communication Technology affects Differentiation Strategy significantly. [4] Information \& Communication Technology affects Company Performance but insignificance. [5] Differentiation Strategy affects Company Performance significantly.
\end{abstract}

Keywords: SOEs Construction Service; Innovation Management; ICT; Differentiation Strategy

\section{Introduction}

\subsection{Situation of Construction Service Companies in In- donesia}

Construction services industry includes all parties involved in the construction process including professionals, construction supervisors, as well as suppliers who jointly meet the needs of the industry[1]. According to[2], quoted from the dissertation titled "Competitive Strategy of Contractors in Hong Kong", the construction industry is often defined in accordance with the form of activities and products that produced. The activities are including planning, design, construction, repair and maintenance, and demolition. The products are including buildings, airports, seaports, electrical, communications, gas works, reclamation, drainages, dams, pipelines, canals, railroads, reservoirs, and tunnels. Tan Yong Tao also explain that the construction industry is engaged in service \& product sectors such as material and equipment manufacturing, material supply, public agencies, professional consultants, building contractors, \& civil engineering contractors.

Based on the previous description, as an effort to produce products in the form of infrastructure and physical facilities, the construction industry has a very important role for national development, especially in the context of national economic growth. In addition to providing these infrastructure and physical facilities, the construction industry as a foundation for economic growth also has several roles, among others: supporting business and employment opportunities; growth driver of other sectors; contributor of gross domestic product; supporting increased savings of foreign exchange users and increased foreign exchange earnings; media transfer of technology knowledge; media for formation of work ethic, discipline, awareness of responsibility, efficiency, and effectiveness; supporting the enhancement of national resilience; as well as the media of national pride.

The growth of construction service companies is comparable or positively correlated with Indonesia's GDP growth reported by Central Bureau of Statistics as in the following table:

Table 1: The Number of National and Foreign Construction Services Companies [2013]

\begin{tabular}{|l|l|l|l|l|l|}
\hline \multirow{2}{*}{ No } & \multirow{2}{*}{ Qualification } & \multicolumn{2}{|l|}{$\begin{array}{l}\text { National Construc- } \\
\text { tion Services Com- } \\
\text { panies }\end{array}$} & \multicolumn{2}{|l|}{$\begin{array}{l}\text { Foreign Construction } \\
\text { Services Companies }\end{array}$} \\
\cline { 3 - 6 } & & Amount & $\%$ & Amount & $\%$ \\
\hline 1 & Big & 2.476 & 2.5 & 129 & 100 \\
\hline 2 & Medium & 6,433 & 6.5 & & \\
\hline 3 & Small & 90,099 & 91.0 & & \\
\hline $\begin{array}{l}\text { Sub- } \\
\text { Total }\end{array}$ & & 99.008 & 100.0 & 129 & 100.0 \\
\hline
\end{tabular}

Source: Central Bureau of Statistics, Construction Statistics, 2015

The increasing of construction activities of government and private projects has attracted many potential newcomers. However, until now the SOEs in Construction Service still play a role in the control of national construction market share[3].

In recent years, more than $50 \%$ of construction works in Indonesia are the type of large construction works [heavy engineering construction] in the form of infrastructure such as roads, seaports, irrigation, power generation, gas and water distribution, and telecommunications. Most of these types of projects are publicly funded and as the Indonesian government's financial capacity is limited, the private sector is included to develop and manage the 
infrastructure projects. Example of project that is most often funded by private sectors is toll road construction.

As one of the important sectors that play a role in the economy, various problems that often occur and cause performance degradation needs to be considered. As an illustration, the problems of construction in developing countries generally among others are:[4];[5];[6] [7] [8]

- High cost of capital import, tech tools, as well as material that could aggravate the balance of payments.

- Lack of skills and materials, including managerial capabilities and weak level of innovation process.

- Financial inadequacies and delay in payments

- Weak planning and administration system

- Dominance of foreign contractors and the lack of capacity of local contractors

- Nonconformance of targets to be achieved through planning in the socio-economic areas that lead to irregular jobs flow, less efficient, and low-quality results

- Lack of competitiveness compared to foreign contractors due to the limitation of funds and technology as well as the inability to innovate, for example looking for the funds with low interest.

- Public awareness of the benefits and the importance of construction service role for the national development still needs to be more improved [2]

To achieve a strong construction services industry, several conditions necessary for good growth have not been met. The conditions needed to robust the construction service industry [9] are as follows:

- The availability of management personnel and professional experts in sufficient quantities

- Raw materials / materials are standardized nationally and produced as needed

- Construction equipment should be obtained easily and competitively

- The information system of construction service industry that proper and open starting from the project conception until the project bidding.

- Introduction to the up to date and efficient construction methods to excel in international bidding.

In general, construction companies in developing countries have problems related to structural weaknesses in the national economy, a mismatch among existing resources, administrative mechanisms and common infrastructure, and techniques and practices taken from outside. For example, we can see the problems of the construction industry in China that frequently occurred are material deficiencies, poor maintenance of equipment, less developed field management, inability to coordinate mechanical services, difficulty for achieving a decent allocation of competent workforce, etc.

To overcome and anticipate these problems, then the measurement of construction activities globally and internationally is necessary. It is Similar to conduct comparison of construction activities internationally. The purpose of this international comparison is to figure out and understand the development of construction industry in each country related to its economic development and to know the standards in each country. In addition, the objective is to provide aggregation data on the countries reviewed in order to formulate international regulation decisions that mutually supportive. The importance of globalization, especially of its potential for the construction industry in poor countries is through technology transfer and innovation[10]. The best answer to face the challenge of globalization is by establishing global cooperation, redistributing tasks among business partners aimed at cost-saving and increasing productivity, establishing an international network for collecting data needed for business, and sharing information and expertise. The benefits of this form of cooperation are quite relevant in the context of the statistics of the construction industry. To face globalization and to anticipate the problems that exist in the construction industry, there are several efforts that can be undertaken by the construction services companies in Indonesia.

Table 2: Total Sales Generated in the Last 4 Years

\begin{tabular}{|c|c|c|c|c|c|}
\hline & Name of SOEs Construction Ser & Sales [IDR & Trillic & & \\
\hline No & & \begin{tabular}{|l|l|}
2012 & 2013 \\
\end{tabular} & 2014 & 2015 & Remark \\
\hline 1 & PT. Adhi Karya & \begin{tabular}{|l|l|}
19.47 & 19.58 \\
\end{tabular} & 20.24 & 27.07 & \\
\hline 2 & PT. Hutama Karya & $N A$ & $N A$ & $N A$ & \\
\hline 3 & PT. Pembangunan Perumahan & \begin{tabular}{|l|l|}
19.47 & 19.58 \\
\end{tabular} & 20.24 & 27.07 & \\
\hline 4 & PT. Waskita Karya & $12: 26 \mid 8.78$ & 21.49 & 32.08 & \\
\hline 5 & PT. Wijaya Karya & $17.13 \mid 17.73$ & 17.63 & 25.22 & \\
\hline
\end{tabular}

Source: Annual Report of ADHI, PP, Waskita, WIKA 2012-2015

From the data shown in Table 2, it can be seen that the total sales generated has increased gradually, but SOEs construction service are still unable to compete with foreign contractors that obtain projects in Indonesia, this is marked by many foreign contractors working in Indonesia, for example Chinese contractors which still dominate the energy works as well as technology specialist contractors such as Freyssinet, VSL, and L\&M. If the SOEs on Construction Service are able to compete with foreign contractors, then the projects will be handled by local contractors.

\subsection{Development of Differentiation Strategy}

Since the financial crisis in 2008, especially in the developing countries, many global companies have changed their competitive strategy from low cost strategies based on competitive prices to be a differentiation strategy[11]. In addition, the focus only on cost leadership strategies is no longer suitable to accommodate diverse customer needs[12].

Essentially, differentiation strategy is a differently designed action to differentiate a company's actions against competitors[13]. Companies that use differentiation strategy consider first activity to market as the top priority. By doing something new and being the first in the market, the company has the policy to set prices, to exploit a broad market segment, and to achieve high profits and significant growth. SOEs construction service create differentiation strategy by developing market share to overseas, performing project with EPC [Engineering, Procurement, and Construction] strategy, and developing project with investment. So, at this moment, SOEs Construction Service must perform differentiation strategy from previously expecting work from government and big private, to doing different action. Other advantages through differentiation strategy can be achieved through good quality product and emphasis on innovation as the cutting edge of the company. According to Porter[14], innovation is the only way for a company to gain sustainable competitive advantage and improve performance. The keyword of innovation is creativity in making changes that ultimately gain commercial value. Creativity is exploiting existing products and creating new products. However, the commercial value of the product is also necessary so that the new invention can be called innovation. That is, if the product of creativity is not useful, then it will have no commercial value.

Besides having the potential to increase growth, innovation can also lead companies to fail in the market and cause harm to the company. The failure can be caused by a lack of understanding on consumers who need products when innovation is not in accordance with market desires. Information and Communication Technology [ICT] supports the creation of innovation through the creation of an environment that fosters creativity, as well as the allocation of resources both in generating accurate market research and creating innovations that received by market. When ICT synergizes with innovation, innovation is seen as an optional and focus on day-to-day operations [daily operations], innovation is hampered, resulting in failure in innovation performance. Therefore, ICT and innovation will be perfect if supported by sophisticated and wellmanaged ICT [[7];[15]. 


\subsection{Research Question}

From the review of the introduction and subject matter, then the research question arises: With the innovation management and ICT that exist today, through differentiation strategy, which are EPC strategy, expansion to overseas, and creating projects with owned capital investment will it increase the performance of SOEs

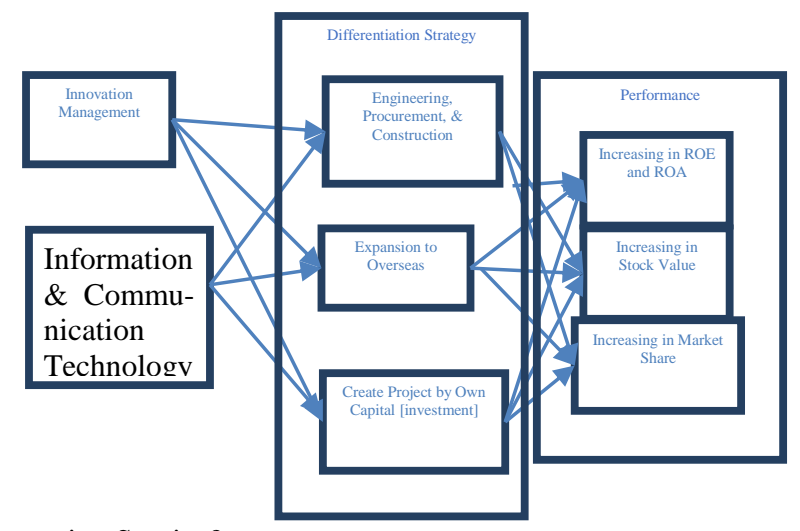

Construction Service?

The research question is illustrated in Figure 1 as follows:

Fig. 1: Research Paradigm

Source: Processed by author

\section{Literature Review}

Differentiation strategy is the act of designing a set of useful distinction to differentiate offerings provided the company from competitors' offerings[13]. A company can differentiate itself in various ways, such as offering innovative features, launching effective promotions, providing superior service, developing strong brand names, and so on.

[16] and [17] stated that organizations that utilize differentiation strategy tend to build differences in various dimensions to make buyers understand the differences between the organizations and their competitors.

Companies with this strategy tend to offer their products at higher prices than competitors and the compensation are unique features, fast shipping costs, service quality, and distribution channels[17]; [14]

In general, the power of differentiation is scarce and expensive to imitate therefore it becomes the source of sustainable competitive advantage. Scarcity will weaken the power of buyers because of the lack or even no alternative products that are comparable to the company's products. Therefore, empirical indicators of differentiation cover rapid introduction of new products/services, offering of different product/service, performance of product/service in various forms, offering of high quality product/service, tailored products, and offering of after-sales service and customer service [18] [19] [20]

\subsection{Innovation Management:}

Innovation Management is the process of managing innovation to produce economic and social success gained efficiently and effectively by enabling all company resources. Innovation Management deals with how to innovate. Successful Innovation Management needs to be supported by innovations that change the way of work of managers. Innovation Management is changing the way of management by abandoning traditional management principles, processes, and practices to meet the demands, needs of the company, interest of stakeholders.

Innovation is the management of all activities related to the process of creating ideas, developing technologies, and product marketing, processing, manufacturing, or new equipment[7]. To create innovation, companies need to create an internal environment that facilitates a culture of innovation characterized by the flexibility and speed to change in response to new opportunities. The four main criteria of innovation include product innovation, process innovation, market innovation, and organizational innovation[7]. The performance of innovation includes how fast, how well the ideas are implemented, and how many values are created.

In order to link the innovations used in the construction industry, then innovation is measured by empirical, innovative performance indicators i.e. introduction of new product and service, percentage of new products in product portfolios, the number of products and services in new projects, innovation process and work methods, quality of new product and service, and update of administration system and mindset.

Dimensions of Innovation Management in this research are:

1 Availability of R \& D Department

2 Risk Taking

3 Openness and Fortitude

4 Failure Acceptance

Source:[21], [22] [7] that have been processed by author.

\subsection{Information and Communication Technology}

Information technology is a big umbrella term that covers all the technical equipment to process and deliver information. Information and Communication Technology [ICT] covers two aspects, i.e. information technology and communication technology. Information technology covers all matters relating to process, use as a tool, manipulation, and management of information. While communication technology is everything associated with the use of tools to process and transfer data from one device to another. Therefore, information technology and communication technology are two inseparable concepts. Thus, ICT contains the broad sense that all activities related to the processing, manipulation, management, and transfer of information between media. The terms of ICT emerged after the fusion of computer technology [both hardware and software] and communications technology in the mid of $20^{\text {th }}$ century. [23]

Information Technology is defined as assembling, storing, and retrieving data in the form of words, numbers, images, and sounds electronically. Gerstein and Callon in [24] stated that information technology is used to create information systems, including the entire hardware and software used to implement a computer-based information systems.

The dimensions of ICT in the study are:

a. Human Resources as operator and programmer and user of information technology.

b. The technology used.

c. Partnership between information technology and management as user.

\subsection{Company Performance}

According to [25] organizational performance refers to the company's ability to achieve high profits, quality product, large market share, good financial results, and corporate sustainability at certain time. To make it happen, a relevant strategy is required. Organizational performance can also be used to see to what extent an organization is able to meet the needs of its stakeholders and its own needs for survival[26]. Furthermore, [27]states that financial performance is traditionally the most common index used to measure organizational performance by researchers. Financial ratio analysis can provide a fairly accurate picture of company performance, useful to compare the performance of several companies with relatively different sizes, relevant to use because of its simplicity, comprehensive, and can be used by all companies, therefore the company performance in this study will use financial performance. Empirical indicator variables are the rate of sales growth, the increase in stock value, and the increase of market share.

\subsection{Hypotheses}

The model in this study is illustrated in Figure 2, this model represents the four variables of Innovation Management, Information \& 
Communication Technology [ICT], Differentiation Strategy, and Performance of SOEs Construction Service.

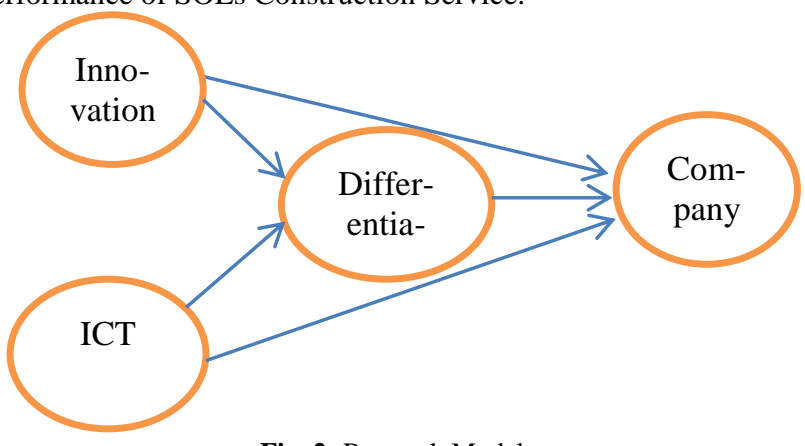

Fig. 2: Research Model

Source: Processed by author

Based on the above research model, the following 5 [five] hypotheses are proposed:

H1: Innovation management affects differentiation strategy;

$\mathrm{H} 2$ : ICT affects differentiation strategy;

H3: Innovation management affects company performance;

H4: ICT affects company performance;

H5: Differentiation strategy affects company performance

\section{Methodology}

\subsection{Data Collection Technique}

Data is collected by using survey method that is by giving list of questions or questionnaire directly to the respondents. The questionnaire is a closed questionnaire consisting of two parts, the first is consists of questions to obtain the respondents' personal data and the second part is used to obtain data about the dimensions of constructs developed in this study. The statements in the closed questionnaire are measured by using the $1-5$ scale to obtain interval data and score is given, for example, the categories of statements with strongly disagree or strongly agree answers.

\begin{tabular}{|l|l|l|l|l|}
\hline Strongly Disagree & $\rightarrow$ & $\rightarrow$ & $\rightarrow$ & Strongly Agree \\
\hline 1 & 2 & 3 & 4 & 5 \\
\hline
\end{tabular}

\subsection{Data Analysis Technique}

This research requires a data analysis and interpretation that will be used to answer the research questions to reveal certain social phenomena, thus data analysis is the process of data simplification into a form that is easier to be read and interpreted. The research model that will be used in this study is a tiered structure model and to test the hypothesis, SEM [Structural Equation Modeling] analysis technique, which is operated by AMOS program, is used. The reason of using SEM is that SEM is a set of statistical techniques that enable the testing of a chain of relationship that is relatively "complicated" simultaneously.

Modeling through SEM also enables a researcher to answer both regressive and dimensional research questions, i.e. measuring the dimensions of a concept[28]. Analysis of research models with SEM can identify the dimensions of a construct and at the same time measure the influence or degree of relationship among the factors that the dimensions have been identified.

\subsection{Respondents}

Respondents in this research are project managers of SOEs Construction Service who selected based on experience and position in the parent company. The total number is 60 people consists of general manager and project manager of SOEs Construction Service as the focus on this research and consist of several companies: 1. PT Wijaya Karya, 2. PT Waskita Karya, 3. PT Adhi Karya, 4. PT Hutama Karya. 5. PT Pembangunan Perumahan. 6. PT Brantas Abhipraya, 7. PT Nindya Karya, 8. PT Wika Beton, 9. PT Adhi Gedung. These nine companies become the focus because these companies have the largest sales and always become pioneers in the performance of construction projects in Indonesia.

\section{Results and Findings}

\subsection{Research Instrument Testing Analysis}

Instrument validity is tested by Pearson Correlation analysis tool between items with total items. If the correlation value is above 0.30 , it indicates that the item is valid. Conversely, if the correlation value below 0.30 , it indicates that the item is invalid and not eligible for inclusion at the next stage[29]. The reliability of the instrument is tested by Cronbach Alpha analysis tool. If the Cronbach Alpha coefficient value is above 0.60, indicates the instrument is reliable, otherwise if the Cronbach Alpha coefficient value is below 0.60 , indicates the instrument is not reliable[29]

Table 3: Validity and Reliability Test of Innovation Management Variable

\begin{tabular}{|c|c|c|c|}
\hline Variable & Indicator / Item & Correlation & Remark \\
\hline \multirow{4}{*}{$\begin{array}{c}\text { Innovation Man- } \\
\text { agement }\end{array}$} & $\begin{array}{c}\text { Availability of R } \\
\text { \& D Department }\end{array}$ & 0.457 & Valid \\
\cline { 2 - 4 } & Risk Taking & 0.514 & Valid \\
\cline { 2 - 4 } & $\begin{array}{c}\text { Openness and } \\
\text { Fortitude }\end{array}$ & 0.496 & Valid \\
\cline { 2 - 4 } & $\begin{array}{c}\text { Failure Ac- } \\
\text { ceptance }\end{array}$ & 0.407 & Valid \\
\hline \multicolumn{3}{|c|}{ Cronbach Alpha =0.822 } & Reliable \\
\hline
\end{tabular}

Source: Data Processing

Based on table 3, it can be seen that Innovation Management variable has a correlation value above 0.30 , so the indicators are valid. Then the Cronbach Alpha coefficient value is above 0.60, which means that the instrument of Innovation Management variable is valid and reliable.

Table 4: Validity and Reliability Test of ICT Variable

\begin{tabular}{|c|c|c|c|}
\hline Variable & Dimensions / Indicators & Correlation & Remark \\
\hline \multirow{3}{*}{ ICT } & $\begin{array}{c}\text { Human Resources as operator } \\
\text { and programmer }\end{array}$ & 0.661 & Valid \\
\cline { 2 - 4 } & The technology used & 0.635 & Valid \\
\cline { 2 - 4 } & $\begin{array}{c}\text { Partnership between ICT \& } \\
\text { Management }\end{array}$ & 0.508 & Valid \\
\hline \multicolumn{3}{|c|}{ Cronbach Alpha $=0.884$} & Reliable \\
\hline
\end{tabular}

Source: Data Processing

Based on the table 4 above, it can be seen that ICT variable has a correlation value above 0.30 , so the indicators are valid. The Cronbach Alpha coefficient value is above 0.60, therefore the instrument of ICT variable is valid and reliable.

The following table shows a complete test of Differentiation Strategy variable.

\begin{tabular}{|c|c|c|c|}
\hline Variable & $\begin{array}{c}\begin{array}{c}\text { Dimensions / Indi- } \\
\text { cators }\end{array} \\
\end{array}$ & Correlation & Remark \\
\hline \multirow{3}{*}{$\begin{array}{l}\text { Differentiation } \\
\text { Strategy }\end{array}$} & $\mathrm{EPC}$ & 0.641 & Valid \\
\hline & Expansion abroad & 0.496 & Valid \\
\hline & $\begin{array}{l}\text { Investment to create } \\
\text { your own project }\end{array}$ & 0.593 & Valid \\
\hline \multicolumn{3}{|c|}{ Cronbach Alpha $=0.898$} & Reliable \\
\hline
\end{tabular}

Source: Data Processing

Based on the table above, it can be seen that Differentiation Strategy variable has a correlation value above 0.30 , so the indicators are valid. The Cronbach Alpha coefficient value is above 0.60 , so that the instrument of Differentiation Strategy variable is valid and reliable. The following table shows a complete test of Company Performance variable. 


\begin{tabular}{|c|c|c|c|}
\hline \multirow{4}{*}{ Table 6: Validity and Reliability Test of Company Performance Variable } \\
\hline \multirow{4}{*}{ Performance } & $\begin{array}{c}\text { Dimensions / } \\
\text { Indicators }\end{array}$ & Correlation & Remark \\
\cline { 2 - 4 } & ROA & 0.713 & Valid \\
\cline { 2 - 4 } & $\begin{array}{c}\text { ROE } \\
\text { Increasing in } \\
\text { Stock Value }\end{array}$ & 0.796 & Valid \\
\cline { 2 - 4 } & $\begin{array}{c}\text { Increasing in } \\
\text { Market Share }\end{array}$ & Valid \\
\hline
\end{tabular}

Source: Data Processing

Based on the above table, it can be seen that Performance variable has a correlation value above 0.30 , so the indicator is valid. The Cronbach Alpha coefficient value is above 0.60, so that the instrument of Performance variable is valid and reliable. Structural Model and Hypotheses Test Result:

Table 7: Examination Results for Goodness of Fit Overall Model Stage I

\begin{tabular}{|c|c|c|c|}
\hline Criteria & Cut-off value & $\begin{array}{c}\text { Model } \\
\text { Result }\end{array}$ & Information \\
\hline Chi Square & $\begin{array}{c}\mathrm{df}=195 ; \text { Sig 5\% } \\
228,580\end{array}$ & 290.576 & Deficient Model \\
\hline & & & \\
\hline CMIN/DF & $\leq 2.00$ & 2.965 & Deficient Model \\
\hline GFI & $\geq 0.90$ & 0.862 & Deficient Model \\
\hline AGFI & $\geq 0.90$ & 0.808 & Deficient Model \\
\hline TLI & $\geq 0.95$ & 0.888 & Deficient Model \\
\hline CFI & $\geq 0.95$ & 0.908 & Deficient Model \\
\hline RMSEA & $\leq 0.08$ & 0.100 & Deficient Model \\
\hline
\end{tabular}

Source: Data Processing

The results of the Goodness of Fit Overall examination based on the picture and table above, it is possible to see that all the criteria show values that are less than good. Thus, a modification of the model is needed to obtain a more appropriate model. The following presents the results of the model modification:

Table 8: Examination Results for Goodness of Fit Overall Model Stage II [after modification indices]

\begin{tabular}{|l|c|c|c|}
\hline Criteria & Cut-off value & $\begin{array}{l}\text { Model } \\
\text { Result }\end{array}$ & Information \\
\hline Chi Square & $\begin{array}{c}\mathrm{df}=195 ; \text { Sig 5\% } \\
=228,580\end{array}$ & 156.425 & Good Fit \\
\hline CMIN/DF & $\leq 2.00$ & 1.700 & Good Fit \\
\hline GFI & $\geq 0.90$ & 0.912 & Good Fit \\
\hline AGFI & $\geq 0.90$ & 0.870 & Marginal \\
\hline TLI & $\geq 0.95$ & 0.960 & Good Fit \\
\hline CFI & $\geq 0.95$ & 0.969 & Good Fit \\
\hline RMSEA & $\leq 0.08$ & 0.060 & Good Fit \\
\hline
\end{tabular}

$$
\text { Source: Processed Data }
$$

From the results of the Goodness of Fit Overall examination based on the picture and table above, it is possible to see that there are 6 criteria that fulfill the Cut-of value so that the model can become feasible. Therefore, the SEM model used in this research is feasible to use, and interpretations can be done to discuss the topic further.

Table 9: SEM Hypotheses Test

\begin{tabular}{|c|c|c|c|c|}
\hline Relationship Between Variables & Coefficient & CR & $\begin{array}{c}\text { P- } \\
\text { value }\end{array}$ & Remark \\
\hline $\begin{array}{c}\text { Innovation Management } \rightarrow \\
\text { Differentiation Strategy }\end{array}$ & 0.824 & 7,394 & 0,000 & Significant \\
\hline $\begin{array}{c}\text { Innovation Management } \rightarrow \text { Com- } \\
\text { pany Performance }\end{array}$ & 0.374 & 2,319 & 0.020 & Significant \\
\hline ICT $\rightarrow$ Differentiation Strategy & 0.160 & 1,201 & 0.230 & Insignificant \\
\hline ICT $\rightarrow$ Company Performance & 0.119 & 2,557 & 0.011 & Significant \\
\hline $\begin{array}{c}\text { Differentiation Strategy } \rightarrow \\
\text { Company Performance }\end{array}$ & 0.451 & 3,034 & 0.002 & Significant \\
\hline
\end{tabular}

$$
\text { Source: Data Processing }
$$

Graphically, after several modifications, structural model testing is presented as follows:

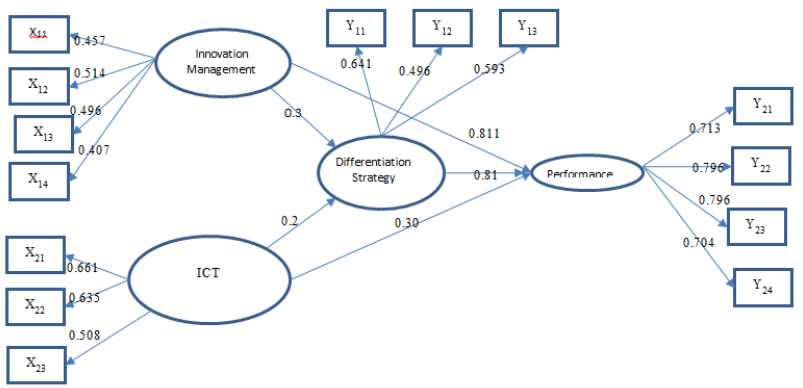

Fig. 3: Structural Graph of Final Stage Model Source: Amos software data processing

\subsection{Discussion}

The results show that the ability of innovation management affects the differentiation strategy. Innovation performance is represented by the number of new products and services that are introduced. If it is accompanied by the changes of administrative system and the mindset of employees, it will be able to improve the company's performance, especially in the form of efficiency and effectiveness as well as increased corporate earnings and total sales. However, this effect is lower than innovation for performance. This means that innovation must generate differentiation of products or services. Otherwise, the effect on the company's performance will not be as powerful as its effect on differentiation strategy.

The results of this study also confirm the literature of Porter [14] which states that innovation is the only way for a company to gain a sustainable competitive advantage and improve its performance. The study also supports the thesis that states the organization's ability to improve innovation management will directly affect the company's performance [[30];[31];[32]]. This study also shows that the effects of innovation management on differentiation strategy will produce a strong and significant effect.

The success of differentiation strategy to create competitive advantage and produce good performance is highly depend on the company's success in innovation[7]. Their innovations are including the provision of EPC projects and expansion to overseas that require innovation in many ways, such as marketing innovation, financial innovation, and process innovation.

This study is also appropriate and confirms the research that states innovation can provide new methods or products that give increased differentiation strategy to outperform its competitors[7];[33]].

\section{Conclusions and Suggestions}

\subsection{Conclusions}

Based on this research, it can be concluded that:

Innovation Management [indicated with Cheng marketing innovation by cooperating local partners, finding new financial resources, and new operational system] affects the Differentiation Strategy [marked with the provision of EPC project and project expansion to overseas].

Management Innovation [indicated by the provision EPC projects and project expansion to overseas] directly affects the Company Performance [indicated by the growth rate and return on sales].

ICT does not affect the Differentiation Strategy [marked with insignificant result of AMOS data processing].

ICT affects the Company Performance [though not great, but still influential].

Differentiation Strategy affects Company Performance significantly [marked by the increase of company share market in overseas]. Suggestions

Based on these results, the researcher suggests the practitioners or leaders of SOEs Construction Service to create an environment that supports the emergence of innovations such as the allocation 
of time, money, and resources to do market research, find references, and empowering employees to experiment.

Through the creation of such atmosphere, the presence of innovation is expected to support a differentiation strategy that will generate a better company performance. The top management of SOEs Construction Service is advised to pay more attention to the development of human resources and to emphasize on ethical practice of the company, among others, through the provision of production and ICT tools usage training.

\section{References}

[1] Hillebrandt PN. Economic Theory and The Construction Industry. London: Macmillan Press; 1985.

[2] Tao TY. Contractor's Competitiveness And Competitive Strategy in Hongkong. A Disertation. 2008.

[3] Construction Service Development Board. 2013.

[4] Ngowi AB, Rwelamila PMD. What is a competitive advantage in the construction industry? Cost Engineering. 1999;41 [2]:30-6.

[5] Triwardono. Sistim bisnis perusahaan yang ideal pada jasa konstruksi di Indonesia. Praproposal Penelitian Program Doktor Pasca Sarjana Teknik Sipil Universitas Indonesia. 2003.

[6] Tao L, Garnsey E, Probert D. Innovation as response to emissions legislation: revisiting the automotive catalytic converter at Johnson Matthey: R\&D; 2010.

[7] Tidd J, Bessant J, Pavitt K. Managing innovation integrating technological, market and organizational change: John Wiley and Sons Ltd; 2005.

[8] Prajogo DI. The Strategic Fit Between Innovation Strategies and Business Environment in Delivering Business Performance. International Journal of Production Economics. 2016;171:241-9.

[9] LPKJ. Laporan Tahunan Lembaga Jasa Konstruksi Indonesia 2014.

[10] Ofori G. Construction Technology development:Role of an appropriate policy. Journal of Engineering, Construction and Architectural Management. 1998.

[11] Gehani R. Innovative strategic leader transforming from low cost strategy to product differentiation strategy. Journal of Technology. 2013.

[12] Poole M. Responsibility for Human Resources Management Practise in the Modern Entreprise: Evidence From Britain Personnel Reviews Journal. 1997.

[13] Kotler, Armstrong. Prinsip-Prinsip Marketing. Jakarta: Salemba Empat; 2003.

[14] Porter ME. The Competitive Advantage of Nations. Harvard business review. 1990;68[2]:73-93.

[15] Dalkir K, Beaulieu M. Knowledge Management in Theory and Practice: MIT Press; 2017.

[16] Li JJ, Zhou KZ. How foreign firms achieve competitive advantage in the chinese emerging economy: managerial ties and market orientation. Journal Business of Research. 2010;63[8]:856-62.

[17] Hilman H. Innovation Strategies and Performance: are they truly linked? . World journal of Entrepreneurship, Management and Sustainable Development. 2015.

[18] Porter ME. Competitive Advantage of Nation. New York, USA: The Free Press; 1990.

[19] Porter M. Technology and competitive advantage. Journal of Business Strategy: Harvard Busines Review 1985.

[20] Porter ME. Competitive Strategy: Techniques for analyzing industries and competitors. New York: Free Press; 1980.

[21] Schumpeter. The Theory of economics development. An inquiry into profit, capital,credit, interest, and the business cycle. Cambridge: Harvard University Press, Reprint Transaction Publisher. 1983.

[22] Porter ME, Heppelmann JE. How Smart, Connected Products Are Transforming Competition. Harvard Business Review. 2014;92[11]:64-88.

[23] Wikipedia.org, accessed on January 20, 2017.

[24] Goodhue RSC. Skill Required of Effective Project Manager. Journal of Management in Engineering. 1993;9[3].

[25] Koontz H, Donnel C. Introduction to Management. New York: McGraw-Hill; 1993.

[26] Norton, Kaplan. Balance Score Card and Execution Premium Ufukpress.com 2010.

[27] Dess, Gregory G, Lumpkin GT. Strategic Management, Creating Competitive Advantage McGraw Hill; 2003.
[28] Ferdinand AT. Structural Equation Modeling dalam Penelitian Manajemen2005.

[29] Sugiyono. Metodologi Penelitian Bisnis. Jakarta: Rineka Cipta; 2005.

[30] Cheng CC, Krumwiede D. The effect of market orientation on new service performance: the mediating role of innovation.2011.

[31] Jimenez-Jimenez D, Sanz-Valle R. Innovation, organizational learning and performance Journal of Business Research. 2011.

[32] Kaliappen N, Hilman H. Does service innovation actas a mediator in differentiation strategy and organizational performance Asian Social Science2014.

[33] Bilgihan A, Okumus F, Kwun DJ. Infromation technology application and competitive advantage in hotel companies. Journal of Hospitality and Tourism Technology. 2011;2[2]:139-54. 